\title{
Pengembangan Aplikasi Augmented Reality Berbasis Android Untuk Visualisasi Struktur Sel Bakteri dan Bentuk-Bentuk Bakteri
}

\author{
Muhammad Dimas Septiandi ${ }^{1}$, Harya Bima Dirgantara ${ }^{2)}$ \\ Informatika, Institut Teknologi dan Bisnis Kalbis \\ Jalan Pulomas Selatan Kav. 22, Jakarta 13210 \\ ${ }^{1)}$ Email: mr.septiand@gmail.com \\ ${ }^{2)}$ Email: harya.dirgantara@kalbis.ac.id
}

\begin{abstract}
The purpose of this research is to develop an Augmented reality applications that was used to visualize the structure of the bacteria cell and bacteria forms in 3 dimensions. An application developed in this research were dedicated to the Android smartphone users are studying or teaching others about the bacteria cell structure and bacteria forms. Software development methods used in the research and application development is incremental. The incremental amounts required in performing this application development amounted to 4 incremental. At each incremental done the analysis, design, coding, and testing phase. 3Ds Max 2018 is used to doing the design of 3-dimensional form of the bacteria. Unity $3 D$ version 5.6.0 f3 and Vuforia library version 6 is used to doing the development of application. The results of this research is the Android-based Augmented reality application for visualization of bacteria cell structure and bacteria forms.
\end{abstract}

Keywords: Android, augmented reality, bacteria, incremental, unity, vuforia

\begin{abstract}
Abstrak: Tujuan dari penelitian ini adalah mengembangkan aplikasi Augmented reality yang digunakan untuk memvisualisasikan struktur sel bakteri dan bentuk-bentuk bakteri secara 3 dimensi. Aplikasi yang dikembangkan dalam penelitian ini ditujukan kepada pengguna smartphone Android yang sedang mempelajari atau mengajarkan orang lain mengenai struktur sel bakteri dan bentuk-bentuk bakteri. Metode pengembangan perangkat lunak yang digunakan dalam penelitian dan pengembangan aplikasi ini adalah incremental. Jumlah incremental yang dibutuhkan dalam melakukan pengembangan aplikasi ini berjumlah 4 incremental. Pada setiap incremental dilakukan analisa, perancangan, pengkodean, dan pengujian. Dalam melakukan perancangan model 3 dimensi bentuk bakteri software yang digunakan adalah 3Ds Max 2018. Dalam melakukan pengembangan aplikasi Augmented reality software yang digunakan adalah Unity $3 D$ versi 5.6.0f3 dan library Vuforia versi 6. Hasil dari penelitian ini adalah aplikasi augmented reality untuk visualisasi struktur sel bakteri dan bentuk-bentuk bakteri berbasis Android.
\end{abstract}

Kata kunci: Android, augmented reality, bakteri, incremental, unity, vuforia

\section{PENDAHULUAN}

Menurut buku Essential Microbiology yang disusun oleh Stuart Hogg, bakteri merupakan mikrobia prokariotik uniselular yang tidak memiliki membran inti sel dan berukuran mikroskopik [1]. Bakteri dapat ditemukan di semua tempat baik di air, tanah, udara, bahkan di dalam tubuh manusia. Beberapa jenis bakteri dapat digolongkan menjadi bakteri yang menguntungkan. Bakteri yang menguntungkan tersebut biasanya bermanfaat bagi industri pangan, industri obat-obatan, dan juga membantu proses pencernaan manusia. Selain bakteri yang menguntungkan bagi kehidupan, terdapat juga bakteri yang dapat merugikan kehidupan manusia. Bakteri yang merugikan kehidupan tersebut merupakan salah satu penyebab dari suatu penyakit atau infeksi. Selain itu bakteri yang merugikan tersebut juga dapat berperan sebagai agen parasit yang hidup dan berkembang di organisme lain.

Bakteri merupakan salah satu pembahasan dalam ilmu biologi yang dipelajari kalangan akademis. Dikarenakan ukuran bakteri yang sangat mikroskopis, maka akan sangat sulit melihat bakteri tanpa alat bantu melihat. Salah satu buku tentang biologi seperti Essential Microbiology yang disusun oleh Stuart Hogg menjelaskan tentang bakteri mulai dari karakteristiknya dan gambar dari bakteri 
tersebut. Namun, gambar yang menunjukan suatu bakteri yang terdapat di dalam buku biologi tersebut masih disajikan dalam bentuk 2 dimensi. Hal tersebut membuat penggambaran mengenai bakteri menjadi kurang rinci. Terdapat cara lain untuk dapat melihat bakteri lebih rinci, yakni dengan menggunakan mikroskop. Namun, biaya yang dikeluarkan untuk membeli seperangkat mikroskop relatif mahal.

Permasalahan-permasalahan tersebut menjadi latar belakang untuk dilakukannya pengembangan aplikasi augmented reality yang dapat digunakan untuk memvisualisasikan bakteri dalam bentuk 3 dimensi.

\section{METODE PENELITIAN}

\section{A. Kerangka Pemikiran}

Penelitian ini dilakukan untuk menghasilkan sebuah aplikasi augmented reality yang dapat digunakan untuk memvisualisasikan bakteri dalam bentuk 3 dimensi. Penelitian ini dibagi menjadi 3 tahap, yaitu tahap pra-penelitian, tahap penelitian, dan tahap pasca penelitian.

Dalam tahap pra-penelitian, kegiatan yang dilakukan antara lain wawancara pengguna aplikasi, mengidentifikasi dan merumuskan masalah, mengkaji pustaka yang membahas tentang bakteri, dan mengkaji penelitian terdahulu mengenai pengembangan aplikasi augmented reality. Hasil yang dihasilkan dari kegiatan di tahap pra-penelitian adalah kebutuhan aplikasi dan referensi mengenai bagaimana aplikasi tersebut akan dikembangkan.

Dalam tahap penelitian, kegiatan yang dilakukan adalah melakukan pengembangan aplikasi dengan menggunakan metode pengembangan perangkat lunak incremental. Jumlah incremental atau tingakatan yang terdapat penelitian ini sebanyak 3 tingkatan. Pada tingkatan pertama atau incremental 1 , proses yang dilakukan adalah membuat model 3 dimensi bakteri menggunakan software 3D Studio Max (3ds Max). Pada tingkatan kedua atau incremental 2, proses yang dilakukan adalah membuat tampilan menu aplikasi menggunakan software Balsamiq. Pada tingkatan ketiga atau incremental 3, proses yang dilakukan adalah meng-import model 3 dimensi bakteri yang telah dibuat pada incremental $1 \mathrm{ke}$ dalam software Unity dan melakukan pengkodean fungsi-fungsi yang dibutuhkan aplikasi. Hasil dari tahap penelitian adalah aplikasi yang dikembangkan.

Dalam tahap pasca penelitian, kegiatan yang dilakukan adalah implementasi aplikasi, pengujian akhir aplikasi, dan evaluasi saran atau masukan dari pengguna. Pengujian yang dilakukan pada tahap pasca penelitian adalah pengujian black box dan pengujian user experience. Secara keseluruhan, penelitian ini dapat diilustrasikan seperti yang terdapat pada Gambar 1.

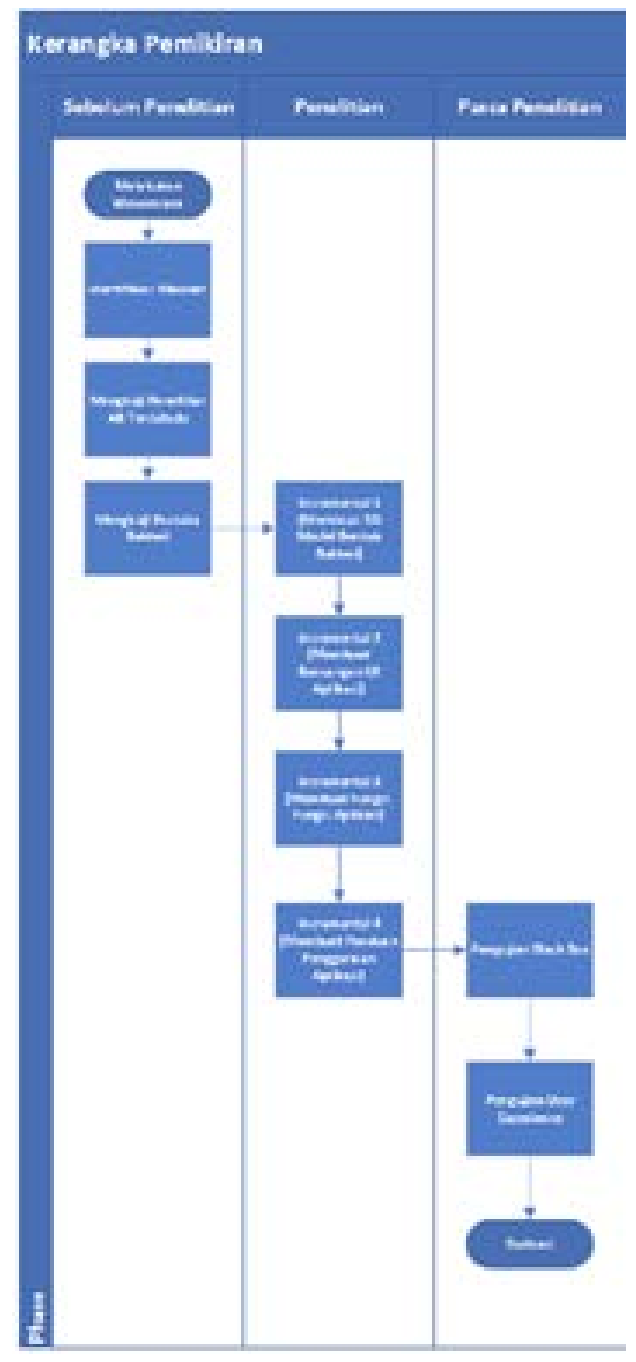

Gambar 1 Kerangka pemikiran

\section{B. Visualisasi}

Berdasarkan buku "Visualization in Scientific Computing" yang disusun oleh Mc. Cormick, B.H, visualisasi adalah metode komputerisasi yang mentransformasikan simbolik menjadi geometrik [2]. Visualisasi menyajikan metode untuk dapat melihat yang tidak dapat dilihat [2].

\section{Augmented Reality}

Berdasarkan buku "Understanding Augmented reality" yang disusun oleh Craig B. Alan dan buku "Emerging Technologies of Augmented reality: Interfaces and Design" yang disusun oleh Michael Haller, Augmented reality merupakan sebuah teknologi yang dikembangkan dengan tujuan menambahkan informasi atau konten digital secara real-time ke dalam dunia nyata [3]. Augmented 
reality memungkinkan pengguna untuk dapat melihat dan berinteraksi dengan objek 3 dimensi virtual yang dihasilkan komputer pada dunia nyata [4]. Penelitian terdahulu menunjukan bahwa augmented reality dapat diimplementasikan pada banyak bidang meliputi pendidikan, medis, militer, manufaktur, dan hiburan [3].

\section{Bakteri}

Berdasarkan buku "Biologi Untuk SMA dan MA" yang disusun oleh Diah Aryulina, bakteri merupakan organisme uniseluler, prokariot, dan umumnya tidak memiliki klorofil [5]. Ukuran tubuh bakteri bervariasi mulai dari 0,12 mikron hingga ratusan mikron [5]. Namun rata-rata bakteri berukuran 1-5 mikron [5].

\section{E. Metode Pengembangan Perangkat Lunak Incremental}

Berdasarkan buku "Software Engineering" yang disusun oleh Roger S. Pressman, metode pengembangan perangkat lunak incremental merupakan kombinasi dari metode pengembangan perangkat lunak linear dengan perulangan dari metode prototyping yang bertingkat [6]. Setiap increment atau tingkatan dari proses pengembangan perangkat lunak harus memliki deliverable atau hasil yang diperoleh dan divalidasi [6]. Berdasarkan buku "Software Engineering", tahapan dalam metode pengembangan perangkat lunak incremental terdiri dari tahap Analisa, perancangan, pengkodean dan pengujian [6].

\section{F. Pengujian Black Box}

Berdasarkan buku "Software Engineering" yang disusun oleh Kassem A. Saleh pengujian black box adalah sebuah teknik yang diterapkan dalam rangkaian kegiatan Software Under Test (SUT) tanpa perlu mengetahui source code dari sistem yang diuji tersebut [7]. Pengujian black box juga disebut sebagai pengujian fungsionalitas [7]. Rangkaian test-case dikembangkan berdasarkan use case dari sistem yang dibuat [7].

\section{G. Pengujian User Experience}

Berdasarkan definisi ISO 9241-210 mengenai User experience (UX) yang dimuat dalam jurnal yang disusun oleh Mendiola B. Wiryawan, UX adalah persepsi dan respon seseorang ketika menggunakan sebuah produk, jasa, atau sistem [8]. UX menilai tingkat kepuasan dan kenyamanan pengguna ketika menggunakan sebuah produk, jasa, atau sistem [8].

\section{H. Use case Diagram}

Berdasarkan buku "Rekayasa Perangkat Lunak" yang disusun oleh Rosa A. S dan M. Shalahuddin, use case diagram merupakan pemodelan kelakuan dari sebuah sistem atau aplikasi [9]. Use case diagram menjelaskan interaksi antara satu atau lebih pengguna dengan sistem yang dibuat menggunakan simbolsimbol [9].

\section{Activity Diagram}

Berdasarkan buku "Rekayasa Perangkat Lunak" karya Rosa A. S dan M. Shalahuddin, activity diagram atau diagram aktivitas menggambarkan alur kerja atau aktivitas dari sebuah sistem atau proses bisnis atau menu yang terdapat pada perangkat lunak menggunakan simbol-simbol [9].

\section{J. Unity}

Berdasarkan buku "Game Development With Unity" yang disusun oleh Michelle Menard dan Bryan Wagstaff, Unity merupakan game engine dan editor yang terintegrasi yang memungkinkan pengembang untuk secara cepat dan efisien membuat objek, meng-import aset eksternal, dan menggabungkannya bersama kode [10]. Editor yang terdapat dalam Unity dibuat secara visual sehingga memungkinkan pengembang untuk dapat melakukan apapun secara mudah dengan teknik drag $\mathrm{n}$ drop, menyisipkan variabel, atau membuat multi-part aset yang rumit [10]. Unity juga terintegrasi dengan tools pengkodean dan memiliki kemampuan untuk membuat dan menyebarkan aplikasi untuk berbagai macam platform [10].

\section{K. Vuforia}

Berdasarkan penjelasan dari website resmi Vuforia, Vuforia merupakan platform untuk pengembangan augmented reality yang mendukung ponsel, tablet, dan eyewear [11]. Para pengembang dapat dengan mudah menambahkan fungsi dari computer vision ke dalam aplikasi Android, iOS, dan UWP [11].

\section{HASIL DAN PEMBAHASAN}

\section{A. Incremental 1}

\section{Analisa}

Berdasarkan wawancara yang dilakukan dengan pengguna aplikasi, dilakukan analisa untuk mengidentifikasi model 3 dimensi bakteri yang menjadi kebutuhan aplikasi. Adapun model 3 
dimensi yang menjadi kebutuhan aplikasi adalah model 3 dimensi struktur sel bakteri dan bentukbentuk bakteri.

\section{Perancangan}

Dalam melakukan perancangan model 3 dimensi struktur sel bakteri dan bentuk-bentuk bakteri, software yang digunakan adalah 3ds Max 2018. Hasil dari perancangan model 3 dimensi struktur sel bakteri dan bentuk-bentuk bakteri terdapat dalam Tabel 1 .

Tabel 1 Hasil perancangan model 3 dimensi bentuk bakteri

\begin{tabular}{|c|c|c|c|}
\hline No. & Nama Objek & Referensi & Objek Yang Dibuat \\
\hline 1. & Monococcus & & \\
\hline 2. & Diplococcus & & \\
\hline 3. & Streptococcus & & \\
\hline 4. & Tetracoccus & & \\
\hline 5. & Sarcina & & \\
\hline 6. & Monobacillus & & \\
\hline 7. & Diplobacillus & & \\
\hline 8. & Streptobacillus & 2 & \\
\hline 9. & Spirochete & & \\
\hline 10. & Vibrio & & \\
\hline
\end{tabular}

\section{Pengkodean}

Berdasarkan penelitian yang dilakukan, pada incremental pertama pengembangan aplikasi augmented reality untuk visualisasi bakteri tidak dilakukan pengkodean. Pengkodean tersebut tidak dilakukan karena objek 3 dimensi yang dibuat hanya berupa objek 3 dimensi statis dan tidak menggunakan animasi.

\section{Pengujian}

Berdasarkan penelitian yang dilakukan, disusunlah daftar pertanyaan untuk melakukan pengujian terhadap model 3 dimensi bentuk bakteri dan model 3 dimensi struktur sel bakteri yang dibuat. Adapun daftar pertanyaan tersebut terdapat pada Tabel 2.

Tabel 2 Pengujian kesesuaian model 3 dimensi bentuk bakteri

\begin{tabular}{|c|c|c|}
\hline No. & Model 3 Dimensi & Pertanyaan \\
\hline 1. & Monococcus & $\begin{array}{l}\text { Apakah model } 3 \text { dimensi } \\
\text { monococcus yang dibuat } \\
\text { telah menyerupai gambar } \\
\text { referensi? }\end{array}$ \\
\hline 2. & Diplococcus & $\begin{array}{l}\text { Apakah model } 3 \text { dimensi } \\
\text { diplococcus yang dibuat } \\
\text { telah menyerupai gambar } \\
\text { referensi? }\end{array}$ \\
\hline 3. & Tetracoccus & $\begin{array}{l}\text { Apakah model } 3 \text { dimensi } \\
\text { tetracoccus yang dibuat } \\
\text { telah menyerupai gambar } \\
\text { referensi? }\end{array}$ \\
\hline 4. & Streptococcus & $\begin{array}{l}\text { Apakah model } 3 \text { dimensi } \\
\text { streptococcus yang dibuat } \\
\text { telah menyerupai gambar } \\
\text { referensi? }\end{array}$ \\
\hline 5. & Sarcina & $\begin{array}{l}\text { Apakah model } 3 \text { dimensi } \\
\text { sarcina yang dibuat telah } \\
\text { menyerupai gambar } \\
\text { referensi? }\end{array}$ \\
\hline 6 & Monobacil & $\begin{array}{l}\text { Apakah model } 3 \text { dimensi } \\
\text { monobacil yang dibuat } \\
\text { telah menyerupai gambar } \\
\text { referensi? }\end{array}$ \\
\hline 7 & Diplobacil & $\begin{array}{l}\text { Apakah model } 3 \text { dimensi } \\
\text { diplobacil yang dibuat } \\
\text { telah menyerupai gambar } \\
\text { referensi? }\end{array}$ \\
\hline 8 & Streptobacil & $\begin{array}{l}\text { Apakah model } 3 \text { dimensi } \\
\text { streptobacil yang dibuat } \\
\text { telah menyerupai gambar } \\
\text { referensi? }\end{array}$ \\
\hline 9 & Vibrio & $\begin{array}{l}\text { Apakah model } 3 \text { dimensi } \\
\text { vibrio yang dibuat telah } \\
\text { menyerupai gambar } \\
\text { referensi? }\end{array}$ \\
\hline 10 & Spirochete & $\begin{array}{l}\text { Apakah model } 3 \text { dimensi } \\
\text { spirochete yang dibuat } \\
\text { telah menyerupai gambar } \\
\text { referensi? }\end{array}$ \\
\hline 11 & Struktur Sel Bakteri & $\begin{array}{l}\text { Apakah model } 3 \text { dimensi } \\
\text { struktur sel bakteri telah } \\
\text { menyerupai gambar } \\
\text { referensi? }\end{array}$ \\
\hline
\end{tabular}

\section{B. Incremental 2}

\section{Analisa}

Berdasarkan penelitian yang dilakukan, proses yang dilakukan pada incremental kedua adalah membuat rancangan User Interface (UI) dari aplikasi augmented reality untuk visualisasi bakteri.

\section{Perancangan}

Dalam melakukan perancangan UI aplikasi, software yang digunakan adalah Balsamiq Mockup 3. hasil perancangan UI aplikasi terdapat dalam Tabel 3. 
Tabel 3 Hasil perancangan UI aplikasi

\begin{tabular}{|c|c|c|}
\hline No & $\begin{array}{l}\text { Rancangan } \\
\text { Tampilan } \\
\text { Antarmuka }\end{array}$ & Keterangan \\
\hline 1. & 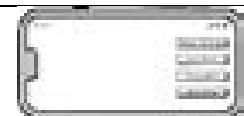 & $\begin{array}{l}\text { Rancangan scene Menu } \\
\text { Utama aplikasi }\end{array}$ \\
\hline 2. & & $\begin{array}{l}\text { Rancangan halaman scene } \\
\text { Struktur Bakteri ketika } \\
\text { pengguna menekan tombol } \\
\text { Struktur Bakteri pada menu } \\
\text { utama aplikasi }\end{array}$ \\
\hline 3. & $=$ & $\begin{array}{l}\text { Rancangan halaman scene } \\
\text { Struktur Bakteri ketika } \\
\text { pengguna menekan bagian } \\
\text { tertentu dari objek } 3 \text { dimensi } \\
\text { struktur sel bakteri }\end{array}$ \\
\hline 4. & & $\begin{array}{l}\text { Rancangan halaman scene } \\
\text { Bentuk Bakteri ketika } \\
\text { pengguna menekan tombol } \\
\text { Bentuk Bakteri pada halaman } \\
\text { utama aplikasi }\end{array}$ \\
\hline 5. & $\sqrt{18}$ & $\begin{array}{l}\text { Rancangan halaman scene } \\
\text { Bentuk Bakteri ketika } \\
\text { pengguna menekan objek } 3 \\
\text { dimensi bentuk bakteri } \\
\text { tertentu }\end{array}$ \\
\hline
\end{tabular}

\section{Pengkodean}

Berdasarkan penelitian yang dilakukan, pada incremental kedua pengembangan aplikasi augmented reality untuk visualisasi bakteri tidak dilakukan pengkodean. Pengkodean tersebut tidak dilakukan karena dalam proses perancangan antarmuka tidak terdapat hal yang harus dilakukan pengkodean.

\section{Pengujian}

Berdasarkan hasil uji paper prototyping yang terdapat pada pengujian di dalam incremental 2, pengguna aplikasi menyatakan bahwa rancangan tampilan aplikasi telah sesuai dengan kebutuhan aplikasi.

\section{Incremental 3}

\section{Analisa}

Berdasarkan wawancara yang dilakukan dengan pengguna aplikasi, dilakukan analisa terhadap fitur apa saja yang menjadi kebutuhkan aplikasi. Adapun hasil analisa tersebut dinyatakan seperti yang terdapat dalam Tabel 4.

\section{Perancangan}

Berdasarkan hasil dari analisa yang telah dilakukan di incremental ketiga, maka pada tahap ini dilakukan perancangan use case diagram dan activity diagram. Ilustrasi mengenai apa yang dapat dilakukan oleh pengguna di dalam aplikasi digambarkan seperti yang terdapat pada Gambar 2.
Tabel 4 Hasil analisa fungsi aplikasi

\begin{tabular}{|c|c|c|}
\hline No. & Scene & Hasil Analisa \\
\hline 1. & $\begin{array}{l}\text { Menu } \\
\text { Utama }\end{array}$ & $\begin{array}{l}\text { 1. Button struktur bakteri yang terdapat } \\
\text { pada scene Menu Utama dapat } \\
\text { mengalihkan pengguna ke dalam scene } \\
\text { Struktur Bakteri ketika ditekan } \\
\text { 2. Button Bentuk Bakteri yang terdapat } \\
\text { pada scene menu utama dapat } \\
\text { mengalihkan pengguna ke dalam scene } \\
\text { Bentuk Bakteri }\end{array}$ \\
\hline 2. & $\begin{array}{l}\text { Struktur } \\
\text { Bakteri }\end{array}$ & $\begin{array}{l}\text { 1. Di dalam scene Struktur Bakteri, } \\
\text { aplikasi dapat memunculkan objek } 3 \\
\text { dimensi struktur sel bakteri ketika } \\
\text { pengguna mengarahkan kamera Vuforia } \\
\text { ke arah marker } \\
\text { 2. Di dalam scene Struktur Bakteri, } \\
\text { aplikasi dapat memperbesar (zoom-in) } \\
\text { dan mengecilkan (zoom-out) ukuran } \\
\text { objek } 3 \text { dimensi struktur sel bakteri } \\
\text { yang muncul } \\
\text { 3. Di dalam scene Struktur Bakteri, } \\
\text { aplikasi dapat merotasi objek } 3 \text { dimensi } \\
\text { struktur sel bakteri pada porosnya } \\
\text { 4. Di dalam scene Struktur Bakteri, } \\
\text { aplikasi dapat menampilkan informasi } \\
\text { mengenai bagian tertentu bakteri ketika } \\
\text { pengguna menekan bagian tertentu dari } \\
\text { objek } 3 \text { dimensi struktur sel bakteri }\end{array}$ \\
\hline 3. & $\begin{array}{l}\text { Bentuk } \\
\text { Bakteri }\end{array}$ & $\begin{array}{l}\text { 1. Di dalam scene Bentuk Bakteri, aplikasi } \\
\text { dapat memunculkan objek } 3 \text { dimensi } \\
\text { bentuk-bentuk bakteri yang telah dibuat } \\
\text { pada incremental 1 } \\
\text { 2. Di dalam scene Bentuk Bakteri, aplikasi } \\
\text { dapat menampilkan informasi mengenai } \\
\text { bentuk bakteri ketika pengguna } \\
\text { menekan salah satu objek } 3 \text { dimensi } \\
\text { bentuk bakteri }\end{array}$ \\
\hline
\end{tabular}

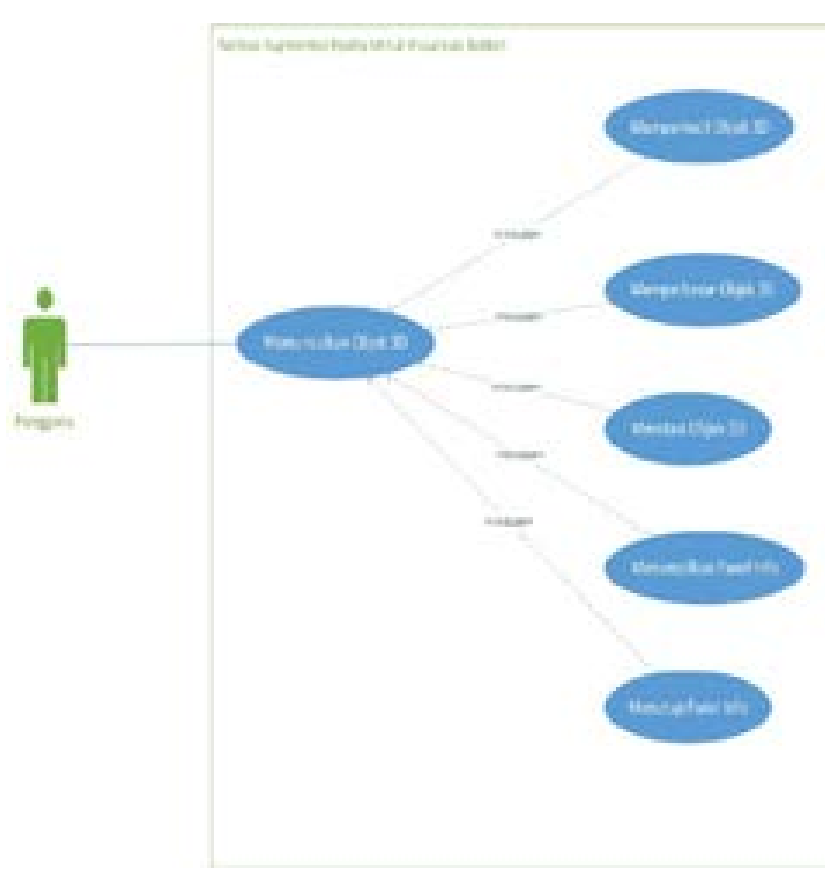

Gambar 2 Use case diagram aplikasi

Berdasarkan use case diagram yang telah dibuat, maka aktivitas pengguna ketika menggunakan aplikasi dan memasuki scene Struktur Bakteri dapat digambarkan dalam activity diagram seperti yang terdapat pada gambar 3 . 


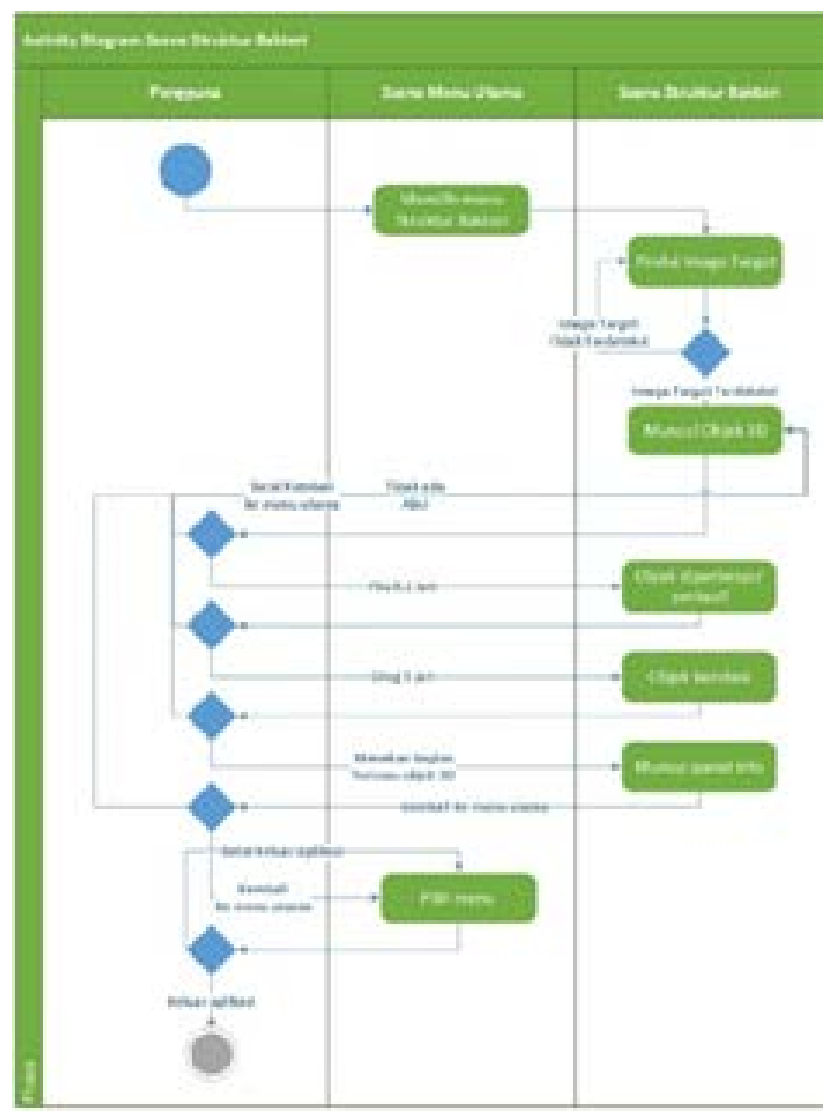

Gambar 3 Activity diagram scenesStruktur bakteri

Berdasarkan use case diagram yang telah dibuat, maka aktivitas pengguna ketika menggunakan aplikasi dan memasuki scene Bentuk Bakteri dapat digambarkan seperti yang terdapat pada gambar 4 .

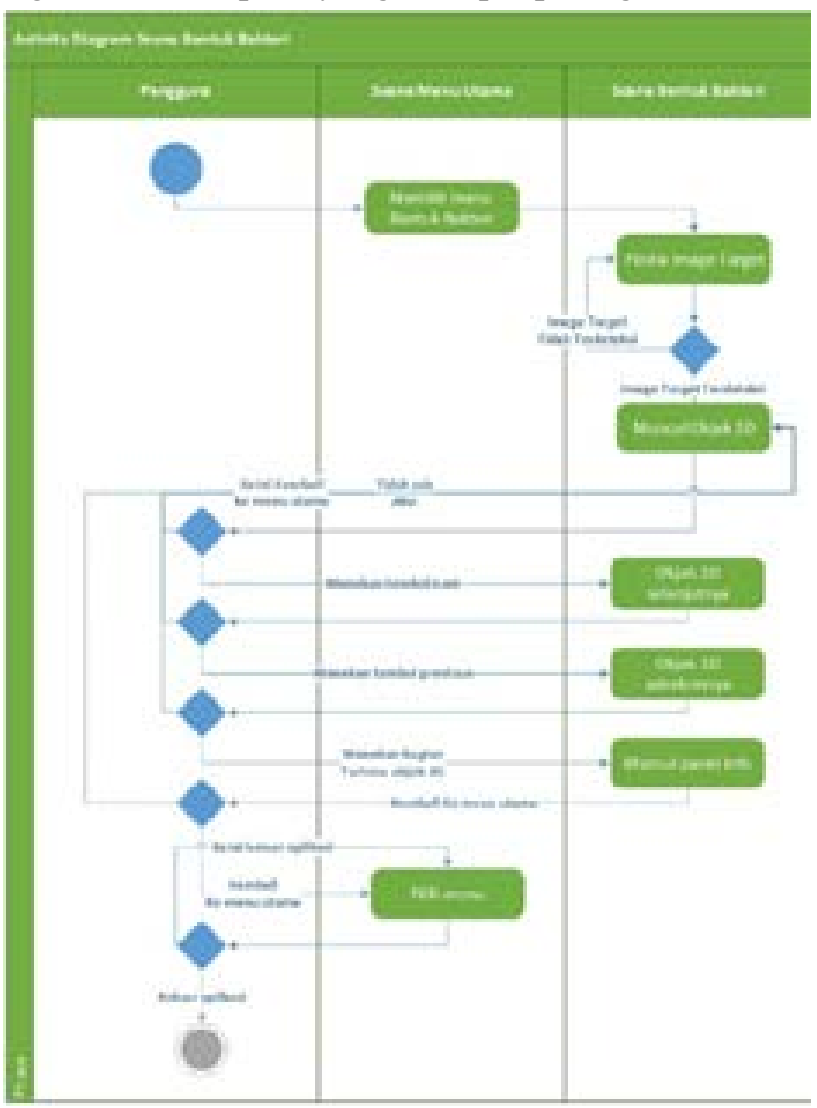

Gambar 4 Activity diagram scene bentuk bakteri

\section{Pengkodean}

Berdasarkan penelitian yang dilakukan, pada incremental ke-3 dilakukan pengkodean $\mathrm{CH}$. adapun pengkodean dilakukan terhadap fungsi peralihan scene, memperbesar objek 3 dimensi, memperkecil objek 3 dimensi, merotasi objek 3 dimensi, manampilkan panel informasi, beralih ke objek 3 dimensi selanjutnya, dan beralih ke objek 3 dimensi sebelumnya.

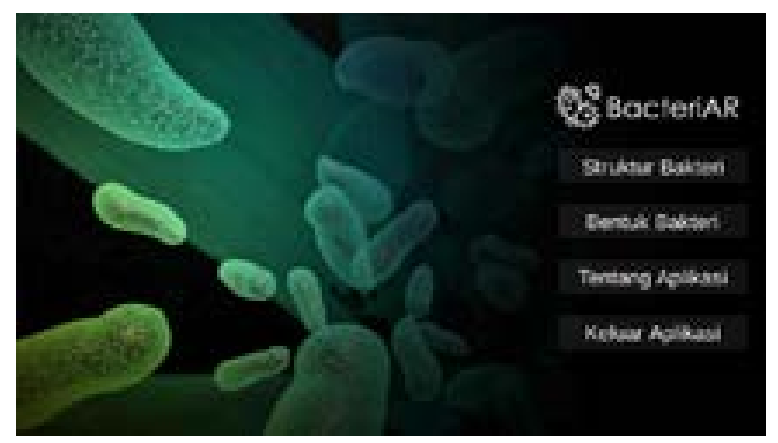

Gambar 5 Tangkap layar menu utama

Pada Gambar 6 merupakan hasil tangkap layar ketika pengguna menakan tombol struktur bakteri yang terdapat di menu utama.

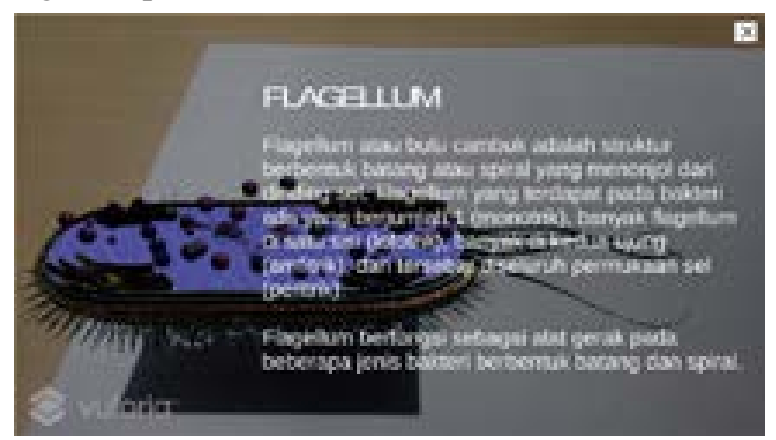

Gambar 6 Tangkap layar scene struktur bakteri

Pada Gambar 7 merupakan hasil tangkap layar ketika pengguna menekan tombol bentuk bakteri yang terdapat di menu utama.

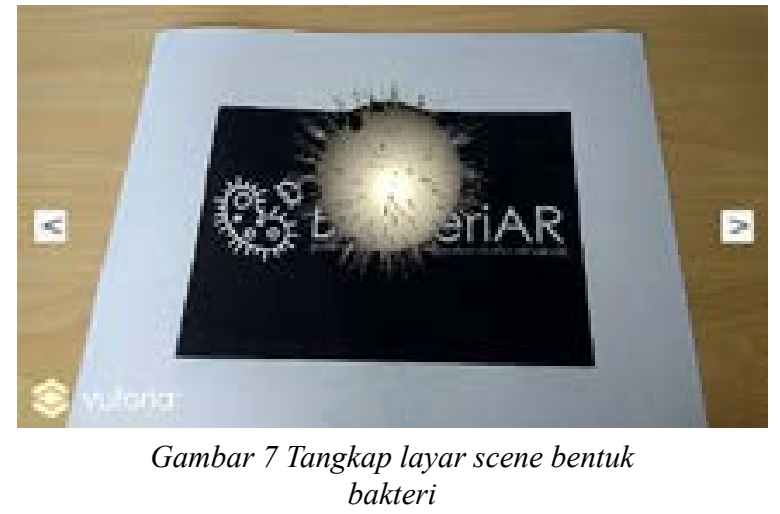

\section{Pengujian}

Berdasarkan penelitian yang dilakukan, pada incremental ke-3 dilakukan pengujian black box 
dengan jumlah skenario sebanyak 33 skenario. Hasil pengujian black box menyatakan bahwa terdapat bug pada 3 panel informasi yaitu panel pili, panel cell wall, dan panel tetracoccus.

\section{Incremental 4}

\section{Analisa}

Berdasarkan hasil pengujian user experience yang dilakukan pada tahap pengujuan di incremental ke-3, didapatkan umpan balik berupa saran dari pengguna yang menyatakan bahwa aplikasi yang dikembangkan dalam penelitian ini butuh panduan penggunaan aplikasi pada scene Menu Utama.

\section{Perancangan}

Berdasarkan analisa yang dilakukan pada incremental ke-4, maka dilakukan pembaharuan terhadap rancangan use case diagram dan activity diagram yang sebelumnya telah dirancang pada incremental ke-3. Pembaharuan use case diagram tersebut terdapat pada Gambar 8.

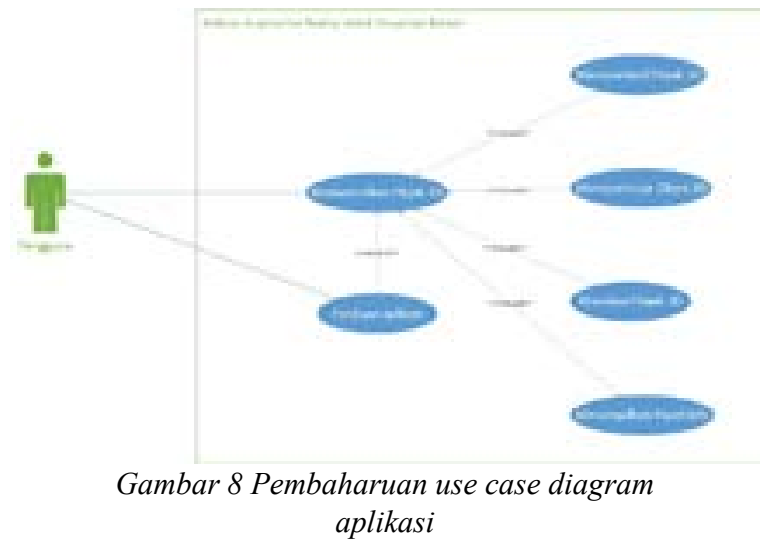

Berdasarkan use case diagram yang telah dirancang pada tahap desain di incremental ke-4, maka dilakukan penambahan 1 activity diagram pada tahap desain di incremental ke-4. Penambahan activity diagram tersebut terdapat pada Gambar 9.

\section{Pengkodean}

Berdasarkan penelitian yang dilakukan, pada incremental ke-4 dilakukan pengkodean $\mathrm{C \#}$. adapun pengkodean dilakukan terhadap fungsi memunculkan panel panduan penggunaan aplikasi dan menutup panel panduan penggunaan aplikasi. Hasil tangkap layar untuk panduan penggunaan aplikasi terdapat pada Gambar 10.

\section{Pengujian}

Berdasarkan penelitian yang dilakukan, pada incremental ke-4 dilakukan pengujian black box dengan jumlah skenario pengujian sebanyak 3 skenario. Berdasarkan hasil uji black box yang dilakukan, fungsi yang diuji telah sesuai dengan skenario pengujian.

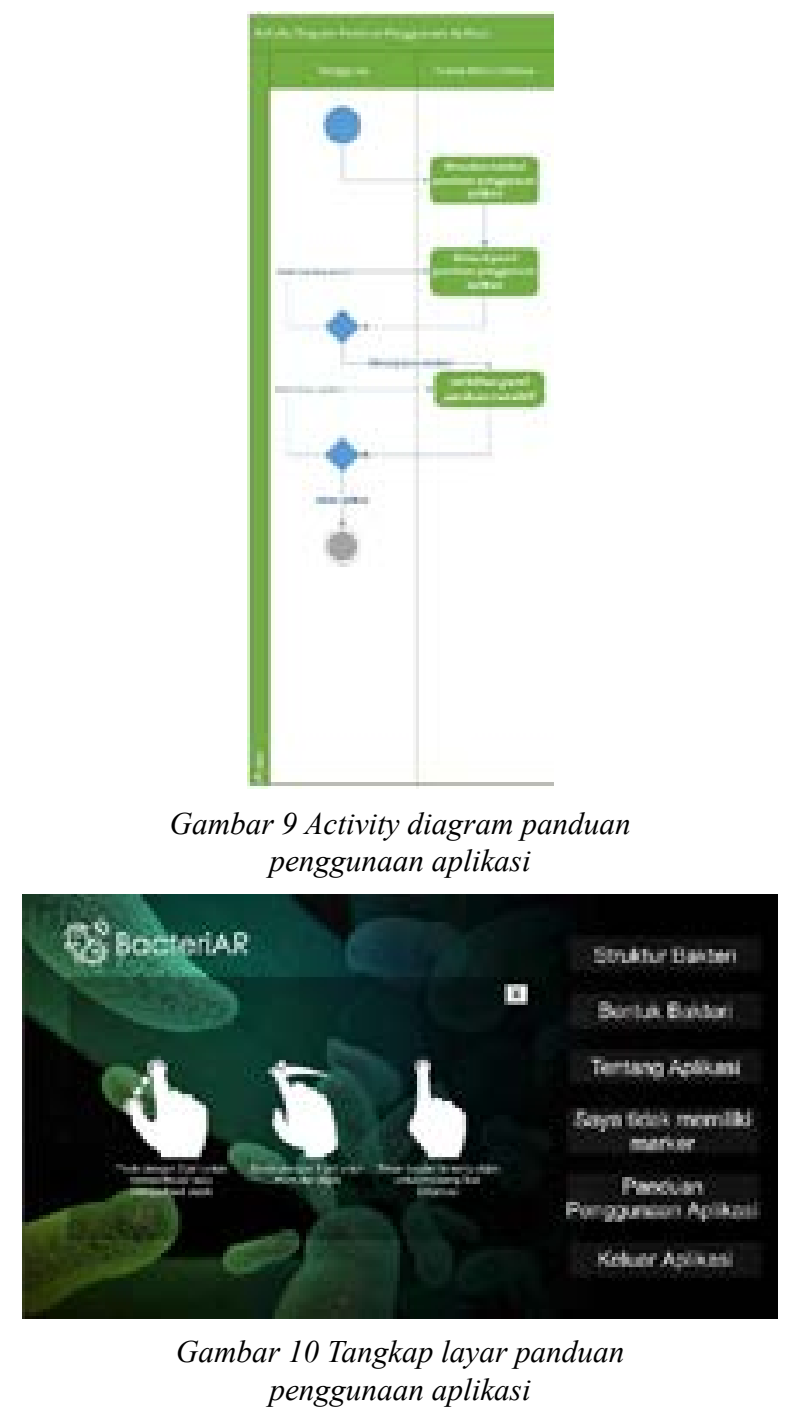

\section{SIMPULAN}

Berdasarkan penelitian yang dilakukan, terdapat beberapa simpulan yang diperoleh dari penelitian ini. Adapun simpulan-simpulan tersebut adalah sebagai berikut: (1) Penelitian ini menghasilkan aplikasi augmented reality untuk visualisasi bakteri berbasis Android; (2) Struktur sel bakteri dan bentuk-bentuk bakteri divisualisasikan dalam bentuk 3 dimensi; (3) Berdasarkan hasil uji black box, terdapat beberapa panel informasi bakteri yang tidak dapat muncul ketika objek 3 dimensi ditekan yaitu panel informasi cytoplasm, panel informasi pili, panel informasi cell wall, dan panel informasi tetracoccus; dan (4) Berdasarkan hasil uji user experience, sebanyak 57\% pengguna menyatakan bahwa informasi dan gambar struktur sel bakteri yang terdapat dalam aplikasi cukup jelas, sebanyak $71 \%$ pengguna menyatakan bahwa informasi dan gambar bentuk-bentuk bakteri 
yang terdapat dalam aplikasi cukup jelas, sebanyak $86 \%$ pengguna menyatakan bahwa beberapa kali terjadi kesalahan input ketika menggunakan aplikasi, dan sebanyak $100 \%$ pengguna menyatakan bahwa aplikasi ini dapat digunakan sebagai media pembelajaran alternatif struktur sel dan bentukbentuk bakteri

\section{DAFTAR RUJUKAN}

[1] S. Hogg, Essential Microbiology, Chichester: John Wiley, hlm. 3-10, 2005.

[2] M. Cormick, Visualization in Scientific Computing, New York: ACM SIGGRAPH, hlm. 15-21, 1988.

[3] Craig and A. B, Understanding Augmented reality: Concepts and Applications, Waltham: Elsevier Inc., hlm. 40-43 2013.

[4] M. Haller, M. Billinghurst and B. H. Thomas, Emerging Technologies of Augmented reality: Interfaces and Design, London: Idea Group Publishing, hlm. 97-103, 2007.

[5] D. Aryulina, C. Muslim, S. Manaf and E. W. Winarni, Biologi Untuk SMA dan MA, Jakarta: Penerbit Erlangga, hlm. 20, 2006.
[6] R. S. Pressman, Rekayasa Perangkat Lunak, Yogyakarta: Andi, 2012.

[7] K. A. Saleh, Software Engineering, Plantation: J.Ross Publishing, hlm. 44-47, 2009.

[8] M. B. Wiryawan, "USER EXPERIENCE (UX) SEBAGAI BAGIAN DARI PEMIKIRAN DESAIN DALAM PENDIDIKAN TINGGI DESAIN KOMUNIKASI VISUAL," vol. 2, no 2. Humaniora, hlm. 1158-1166, 2011.

[9] R. A.S and M. Shalahuddin, in Rekayasa Perangkat Lunak Terstruktur dan Berorientasi Objek, Bandung, Informatika， 2015， hlm. 44-46,125,140-46,154$158,161-163,275-276$.

[10] M. Menard and B. Wagstaff, Game Development With Unity, Boston: Cengage Learning, hlm. 63-67, 2015.

[11] Vuforia, "Vuforia Developer Library," PTC Inc., [Online]. Available: https://library.vuforia.com/. [Accessed 23 Juni 2018]. 